\title{
CHEMICAL AND ORGANOLEPTIC PROPERTIES CHARACTERIZATION OF RICE ANALOG MADE FROM MOCAF, BANANA OR CORN WITH ADDITION OF MUNG BEAN FLOUR
}

\section{KARAKTERISTIK KIMIA DAN ORGANOLEPTIK BERAS ANALOG DARI UBI KAYU, PISANG KEPOK DAN JAGUNG}

\author{
Taufik Hidayat, Wilda Mikasari, Shannora Yuliasari, \\ Lina Ivanti dan Taupik Rahman \\ Balai Pengkajian Teknologi Pertanian (BPTP) Bengkulu \\ Email korespondensi: taufikhidayatveydo@gmail.com
}

Diterima 29-06-2020, diperbaiki 14-10-2020, disetujui 05-11-2020

\begin{abstract}
Rice analog made from locally available flour is one of food diversification to reduce rice consumption. Locally available flour that could be used to make rice analog is mocaf, kepok banana and corn. This study aims to formulate and analyses characteristic of rice analog made from mocaf, kepok banana and corn with addition of mung bean flour. This study using laboratory analysis and consumer preference test. This study divided into three stages; 1. Formulation of rice analog; 2. analysis of chemical characteristic of rice analog; 3. consumer preference test to the rice analog. Observed parameter are chemical characteristic consist of water content, protein, carbohydrate, fat and fiber while the organoleptic characteristic is color, aroma, texture and flavor. Observed data were statistically tested using analysis of variance. The study showed that utilization of mocaf, kapok, banana and corn to make rice analog produce rice analog with different color and texture. The best formula to produce rice analog based on organoleptic test is formula using mocaf flour $80 \%$ with mung bean flour 20\%. Chemical analysis of rice analog using mocaf flour were protein content 8.24\%; fat 0.73\%; carbohydrate $77.97 \%$; fiber $1.87 \%$, water $9.72 \%$ and ash $1.47 \%$. Organoleptic test showed that consumer preference towards rice analog made from modified cassava flour (mocaf) higher than other rice analog.
\end{abstract}

Keywords: Characteristics, organoleptic, rice analog

\begin{abstract}
ABSTRAK
Beras analog merupakan salah satu diversifikasi pangan yang terbuat dari berbagai macam tepung berbahan baku lokal yang dapat menjadi bahan pangan alternatif pengganti beras. Bahan baku lokal yang dapat diolah menjadi beras analog antara lain ubi kayu, pisang kepok dan jagung. Penelitian ini bertujuan untuk membuat formulasi dan menganalisis karakteristik beras analog berbahan baku ubi kayu, pisang kepok dan jagung dengan penambahan tepung kacang ijo. Penelitian dilakukan di Laboratorium pascapanen BPTP Balitbangtan Bengkulu dengan menggunakan metode uji analisis laboratorium dan uji preferensi konsumen. Penelitian dibagi menjadi tiga tahap, yaitu (1) Penentuan formulasi beras analog, (2) Menganalisis karakteristik kimia beras analog, dan (3) Uji preferensi konsumen terhadap produk beras analog. Parameter yang diamati adalah karakteristik kimia yang meliputi kadar air, protein, karbohidrat, lemak, dan serat serta karakteristik organoleptik yang meliputi warna, aroma, tekstur dan rasa. Karakteristik kimia beras analog dan organoleptik nasi dari beras analog diuji dengan analisis sidik ragam. Hasil penelitian menunjukkan bahwa pemanfaatan ubi kayu, pisang kepok dan jagung dalam pembuatan beras analog mampu menghasilkan beras analog
\end{abstract}


dengan warna dan tekstur yang berbeda. Formulasi terbaik berdasarkan uji organoleptik adalah formulasi tepung ubi kayu (mocaf) $80 \%$ dengan penambahan tepung kacang hijau $20 \%$. Hasil analisis proksimat terhadap produk beras analog tepung mocaf yaitu kadar protein 8,24\%, lemak $0,73 \%$, karbohidrat $77,97 \%$, serat $1,87 \%$, air $9,72 \%$, dan abu $1,47 \%$. Hasil uji organoleptik nasi dari beras analog menunjukkan bahwa karakteristik organoleptik nasi yang paling disukai responden adalah yang diolah dari beras analog berbahan baku tepung mocaf.

Kata Kunci: Karakteristik, organolpetik, beras analog

\section{INTRODUCTION}

Rice is an important agriculture product that supply half world population as staple foods (FAO, 2016). Rice production and consumption was concentrated in Asia where most of its habitants consume rice as main staple foods (Mohanty et al, 2010). Rice cultivated on all continent globally except for Antarctica. Rice stock that traded international only up to $5 \%$ of its total production, which makes the price depends on available stock that uncertain due climate change, soil degradation and political policy in exporter countries such as China, India, Indonesia, Bangladesh and Vietnam (Jamal et al, 2014; Muthayya et al, 2014). The importance of rice stock showed in early 2008 when global rice production dropped, exacerbate with in elastic rice demand, price of rice in international market increase tripled only in six months (Jamal et al., 2014; Mohanty et al., 2010).

Rice consumption increased in trends. Although $90 \%$ rice consumption in Asia, rice consumption on non-Asia country keep increased every year such as in Latin America and Caribbean countries, sub Saharan country, Europe and America (Muthayya et al., 2014; USDA, 2014). Rice consumption growth worldwide due to population growth (Asia, Latin America and Africa) and rice consumption per capita in Europe, Australia and North America (Fairhurst \& Dobermann, 2002). Globally, $20 \%$ human calorie intake came from rice (Zeigler \& Barclay, 2008). Rice supply 50\% dietary intake of 520 million poor people in Asia (Muthayya et al, 2014).

Rice is staple food in Indonesia, which makes its consumption is high. Due to its high consumption, Indonesian government made necessary policy to fulfil this need in urgent condition to import rice from other country which unfavorable for local farmers. Various food diversification program has been done to substitute rice with other staple food. However, rice popularity in society was irreplaceable.

Foods diversification based on local resources is one of policy to achieve food sustainability. Indonesian should not only depend on one staple food which is rice. One effort to achieve this goal is to convert local resources as the carbohydrate resources in form of flour. Food technology development allowed food diversification by utilizing carbohydrate source that locally available into products that accepted by Indonesian. One of the products could be in forms of rice analog.

Rice analog is one solution that developed to diversifies staple foods or utilize new carbohydrate source. Rice analog is an artificial rice which made of tuber and cereal that has shape and nutrient content similar to rice. Rice analog could be made from combination of locally available flour (Budi et al, 2013; Budijanto \& Yuliyanti, 2012; Yuwono et al, 2015). Rice analog characteristic more acceptable in society due to its shape and flavor are like rice therefore people don't have to change consumption pattern because rice analog consumption like conventional rice.

In Bengkulu Province, locally available food sources are cassava, corn and kepok banana due to its high availability. Cassava harvest area in 2015 was 3.753 ha with production 80.309 ton and productivity 22.5ton/ha, while corn harvest area in 2015 was 10.137 ha with production 52.785 ton and productivity 5,2 ton/ha (BPS, 2017). Therefore, it is necessary to utilize cassava, 
one of it is to use it as rice analog. Rice analog will be made from combination of cassava, kepok banana and corn as locally available food source in Bengkulu Province. In this study, cassava flour used in form of modified cassava flour.

\section{MATERIAL AND METHODS}

This study was done in postharvest laboratory of Assessment Institute for Agriculture Technology of Bengkulu (AIAT Bengkulu). Main materials for this study were mocaf (modified cassava flour), kepok banana and corn. Mung bean flour were used as additional material act as protein sources in rice analog. Tools used in this study were oven, noodle maker, knife, bucket, sieve, steamer, grinder, stove and other measurement tools. Chemical analyses were done by chemical laboratory, Math and Natural Science University of Bengkulu.

Mocaf flour made according to Amanu \& Susanto (2014), with modification in starter organism, in this study Bimo-CF was used as starter organism. Phase to produce mocaf flour were cassava washing/cleaning, chipping, immersion in starter solution, drying, milling and sifting. Fermentation were done for 12 hours. Drying process took times around 2 days using waring and tarpaulin. After its dried, it's the floured using flouring machine and then sifting to achieve fine texture.

Kepok banana flour made according to Harefa \& Pato (2017) while Corn flour made according to Aini et al, (2010) without fermentation. Kepok banana flour made through peeling, washing/cleaning, cutting/chipping, drying, milling and sifting. Corn flour made by dry process through coarse milling, washing and immersion for 3 hours, drying at room temperature, milling and sifting.

This study consists of three phases, (1) Determination of rice analog formula; 2) Rice analog chemical characteristic analyses; and (3) Consumer preference test to rice analog. Rice analog formula determined through trial and error methods. First, determination percentage of adhesive that made from tapioca and sago flour and determination of rice analog nutrient content. Treatment in this study was utilization of locally available food flour and mung bean flour to make rice analog. Study design used was non factorial complete random design that consist of utilization of flours such as mocaf (m), banana flour (p), corn flour (j) and mung bean flour $(\mathrm{k})$.

The first phase was to define adhesive percentage in rice analog composition with formula:

Table 1. Composition of adhesive in rice analog

\begin{tabular}{clccc}
\hline No & \multicolumn{1}{c}{ Adhesive Agent } & Composition $(\mathrm{g})$ \\
\hline 1. & Sago & 5 & 7,5 & 10 \\
2. & Tapioca & 5 & 7,5 & 10 \\
\hline
\end{tabular}

Table 2. Rice analog from local flour and mung bean

\begin{tabular}{|c|c|c|c|c|c|}
\hline No & Main Ingredient & \multicolumn{4}{|c|}{ Composition Formula } \\
\hline 1 & Mocaf Flour & $\mathrm{m} 1 \mathrm{k} 1$ & & $\mathrm{~m} 2 \mathrm{k} 2$ & $\mathrm{~m} 3 \mathrm{k} 3$ \\
\hline 2 & Banana Flour & p1k1 & & $\mathrm{p} 2 \mathrm{k} 2$ & $\mathrm{p} 3 \mathrm{k} 3$ \\
\hline 3 & Corn Flour & $\mathrm{j} 1 \mathrm{k} 1$ & & $\mathrm{j} 2 \mathrm{k} 2$ & $\mathrm{j} 3 \mathrm{k} 3$ \\
\hline legend: & & & $\mathrm{m} 3 \mathrm{k} 3$ & : Moc & Iung bean $30 \%$ \\
\hline $\mathrm{m}$ & : Mocaf flour & & $\mathrm{p} 1 \mathrm{k} 1$ & : Ban & Mung bean $10 \%$ \\
\hline $\mathrm{p}$ & : Banana flour & & $\mathrm{p} 2 \mathrm{k} 2$ & : Ban & Mung bean $20 \%$ \\
\hline $\mathrm{j}$ & : Corn flour & & $\mathrm{p} 3 \mathrm{k} 3$ & : Ban & Mung bean $30 \%$ \\
\hline $\mathrm{k}$ & : Soybean flour & & $\mathrm{j} 1 \mathrm{k} 1$ & : Corı & \\
\hline $\mathrm{m} 1 \mathrm{k} 1$ & : Mocaf flour $90 \%$, Mung bean $10 \%$ & & $\mathrm{j} 2 \mathrm{k} 2$ & : Corı & Iung bean $20 \%$ \\
\hline $\mathrm{m} 2 \mathrm{k} 2$ & : Mocaf flour $80 \%$, Mung bean $20 \%$ & & $\mathrm{j} 3 \mathrm{k} 3$ & : Cor & Iung bean $30 \%$ \\
\hline
\end{tabular}


Adhesive formulation was intended to get appropriate composition in rice analog formula. Rice analog made by mixing the flour with adhesive that has been cooked and then added water, slowly stirred until the dough become stiff. The dough then mounted onto noodle maker and cut into rice size. Steamed for 30 minutes then oven dried for 6 hours. Formula and composition of rice analog were showed in Table 2 .

Table 3. Rice analog formula

\begin{tabular}{cccccc}
\hline & \multicolumn{5}{c}{ Composition for each treatment } \\
\cline { 2 - 6 } Formula & $\begin{array}{c}\text { Mocaf flour }(\mathrm{m}) \\
\%\end{array}$ & $\begin{array}{c}\text { Banana flour } \\
(\mathrm{p})\end{array}$ & $\begin{array}{c}\text { Corn flour }(\mathrm{j}) \\
\%\end{array}$ & $\begin{array}{c}\text { Mung bean flour } \\
\%\end{array}$ & $\begin{array}{c}\text { Tapioca flour } \\
(\mathrm{g})\end{array}$ \\
\hline 1 & 90 & 0 & 0 & 10 & 7.5 \\
2 & 80 & 0 & 0 & 20 & 7.5 \\
3 & 70 & 0 & 0 & 30 & 7.5 \\
1 & 0 & 90 & 0 & 10 & 7.5 \\
2 & 0 & 80 & 0 & 20 & 7.5 \\
3 & 0 & 70 & 0 & 30 & 7.5 \\
1 & 0 & 0 & 90 & 10 & 7.5 \\
2 & 0 & 0 & 80 & 20 & 7.5 \\
\hline
\end{tabular}

Processed data, 2017

Procedure to produce rice analog consist of mixing, molding, steaming, and drying. Before mixing process, adhesive agents which made of tapioca \& sago flour were cooked with water, stirred until thicken. Adhesive mixture then mixed with the flour, until dull and then molded into rice similar shaped.

The Manufacturing stage of rice analog

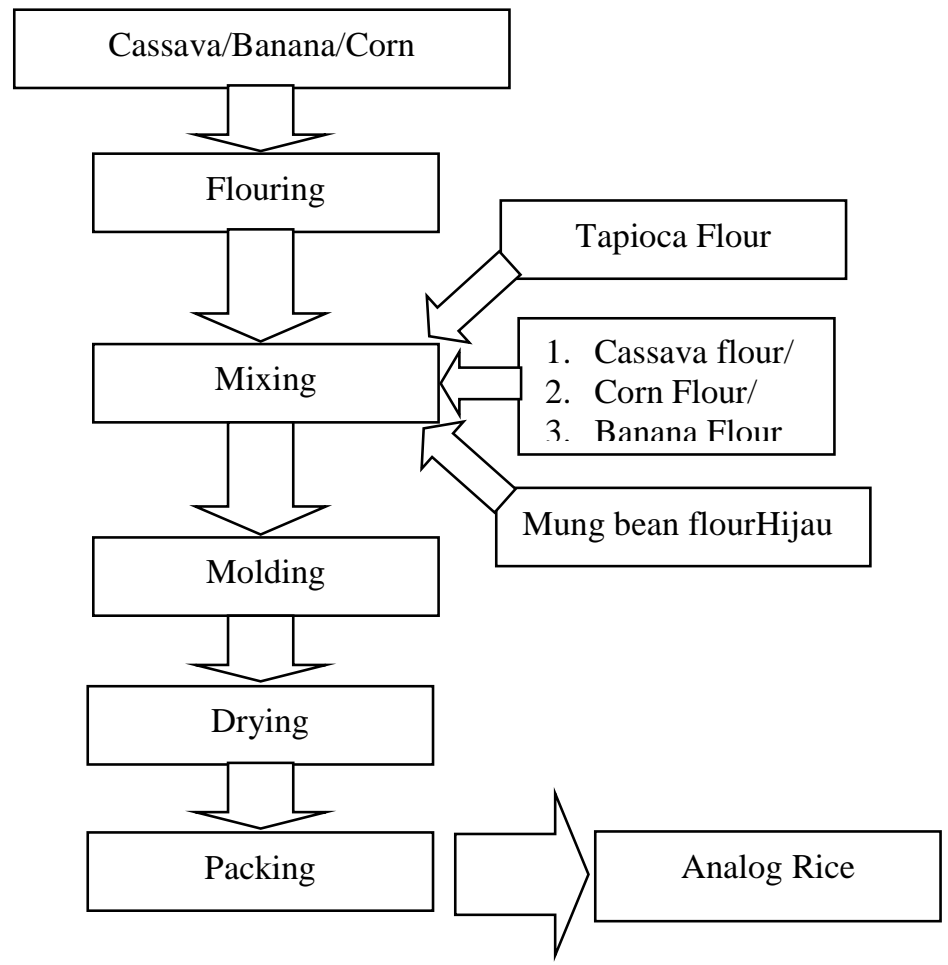

Figure 1. Diagram of Rice analog manufacture process Analog 
Second phase of study was to analyse proximate component in rice analog in Chemical Laboratory, Math and natural science faculty University of Bengkulu laboratory. Chemical analysis of rice analog consist of water content, ash content, protein content, fat content, carbohydrate content and energy content (kkal/100 g). (AOAC Official Method 968.08, 1996).

Third phase of study was to test consumer preference to rice analog with 30 panelists. In this study panelists are person that spontaneously wanted to be a tester. Hedonic test in this study intended to understand panelist preference to produced rice analog. Organoleptic test was done to understand consumer preference to color, scent, texture, taste and appearance as general using hedonic test with scale 1 to 5 . Scale 1 (very dislike), Scale 2 (dislike), scale 3 (rather dislike), scale 4 (neutral), scale 5 (rather like), scale 6 (like) and scale 7 (very like) (Soekarto, 1985). Collected data were statistically analyses using Analysis of Variance (ANOVA) with software SPSS 21. Duncan Multiple Range Test (DMRT) test were done for further analysis.

\section{RESULTS AND DISCUSSION}

\section{Determination of rice analog formula}

Determination of rice analog formula were done through trial and error methods that consist of two phases; determination of adhesive percentage that made of tapioca and sago flour; and determination of rice analog composition. Tapioca and sago flour composition were $5 \%, 7.5 \%$, and $10 \%$. Adhesive from tapioca $7.5 \%$ yield rice analog with solid texture and not easily broken therefore it was decided as adhesive in the rice analog preparation. Preference test to composition of adhesive used in the rice analog were showed in Table 3.

Table 4. Rice analog texture of adhesive composition

\begin{tabular}{clccc}
\hline No & Adhesive composition & Mocaf flour & Banana Flour & Corn Flour \\
\hline 1. & Tapioca 5\% & Loose & Loose & Loose \\
2. & Tapioca 7,5\% & Solid & Solid & Solid \\
3. & Tapioca 10\% & Solid & Solid & Solid \\
4. & Sago 5\% & Loose & Loose & Loose \\
5. & Sago 7,5\% & Solid & Solid & Loose \\
6. & Sago 10\% & Solid & Solid & Solid \\
\hline
\end{tabular}

Processed data, 2017

Tapioca flour has higher starch content and lower carbohydrate content compared to sago flour. Starch has important role in food texture, when mixture of starch and water heated it will form gel. Starch that has been transformed into gel were irreversible where the starch molecules stick together to form a mass that increased its viscosity.

Tapioca flour could be used as adhesive in the rice analog preparation. Addition $7.5 \%$ tapioca flour into rice analog dough (mocaf flour, banana flour and corn flour) would produce rice analog that has better texture, appearance and more solid. Tapioca flour has amylose and amylopectin that influence solubility of sago starch and gelatinization temperature. If amylose content is high, therefore the starch will be dried, less sticky and absorb more water.

\section{Chemical characteristic of rice analog}

Based on chemical analysis of rice analog (Table 5), rice analog with the highest protein content was rice analog that made from banana flour and mung bean. Protein content determined by manufacturing condition and ingredient used. Increased temperature during drying process increase the number of denaturized proteins.

Addition of mung bean flour has significant impact to protein content in banana flour and cassava flour dough, while 
for corn flour dough it has no significant impact on protein content. Bosawer (2010) study showed that, protein content of cassava $1,88 \%-2,45 \%$ and carbohydrate content $98,37 \%-99.18 \%$. Addition of mung bean flour has increase protein content of rice analog to $8,13 \%-8,54 \%$ inline to the added mung bean flour.

Rice analog with the lowest fat content which is $0.56 \%$ was rice analog with mixture of banana flour and 10\% mung bean flour. Rice analog with the highest fat content was made from mixture $80 \%$ corn flour and $20 \%$ mung bean flour with fat content $2,11 \%$. This might because some component, such as carotenoid, that soluble in fat were broken down due to heat and released into rice analog and measured as fat in proximate analysis.

Chemical characteristic of rice analog based on proximate analysis showed in table 5 .

Table 5. Chemical analysis of rice analog from locally available and mung bean flour

\begin{tabular}{clcccccc}
\hline & & \multicolumn{5}{c}{ Analysis parameter } \\
\cline { 3 - 7 } No & Formula & $\begin{array}{c}\text { Protein } \\
(\%)\end{array}$ & $\begin{array}{c}\text { Fat } \\
(\%)\end{array}$ & $\begin{array}{c}\text { Carbohydrate } \\
(\%)\end{array}$ & $\begin{array}{c}\text { Fiber } \\
(\%)\end{array}$ & $\begin{array}{c}\text { Water } \\
(\%)\end{array}$ & Ash $(\%)$ \\
\hline 1. & $\mathrm{~m} 1 \mathrm{k} 1$ & $8,13 \mathrm{a}$ & $1,35 \mathrm{c}$ & $79,63 \mathrm{f}$ & $1,34 \mathrm{a}$ & $8,45 \mathrm{~d}$ & $1,11 \mathrm{a}$ \\
2. & $\mathrm{~m} 2 \mathrm{k} 2$ & $8,24 \mathrm{ab}$ & $0,73 \mathrm{bc}$ & $77,97 \mathrm{bc}$ & $1,87 \mathrm{~b}$ & $9,72 \mathrm{f}$ & $1,47 \mathrm{~b}$ \\
3. & $\mathrm{~m} 3 \mathrm{k} 3$ & $8,54 \mathrm{~b}$ & $0,86 \mathrm{c}$ & $79,22 \mathrm{c}$ & $1,72 \mathrm{~b}$ & $7,69 \mathrm{~b}$ & $1,97 \mathrm{~d}$ \\
\hline 4. & $\mathrm{p} 1 \mathrm{k} 1$ & $9,04 \mathrm{c}$ & $0,56 \mathrm{a}$ & $78,09 \mathrm{bc}$ & $2,12 \mathrm{c}$ & $8,23 \mathrm{c}$ & $1,96 \mathrm{~d}$ \\
5. & $\mathrm{p} 2 \mathrm{k} 2$ & $9,36 \mathrm{~cd}$ & $0,62 \mathrm{ab}$ & $78,04 \mathrm{bc}$ & $2,62 \mathrm{~d}$ & $7,39 \mathrm{a}$ & $1,97 \mathrm{~d}$ \\
6. & $\mathrm{p} 3 \mathrm{k} 3$ & $9,62 \mathrm{~d}$ & $0,84 \mathrm{c}$ & $78,26 \mathrm{c}$ & $1,45 \mathrm{a}$ & $7,83 \mathrm{~b}$ & $2,00 \mathrm{~d}$ \\
\hline 7. & $\mathrm{j} 1 \mathrm{k} 1$ & $7,95 \mathrm{a}$ & $1,83 \mathrm{f}$ & $78,01 \mathrm{ab}$ & $1,86 \mathrm{~b}$ & $8,86 \mathrm{e}$ & $1,49 \mathrm{~b}$ \\
8. & $\mathrm{j} 2 \mathrm{k} 2$ & $7,89 \mathrm{a}$ & $2,11 \mathrm{~g}$ & $78,85 \mathrm{~d}$ & $1,86 \mathrm{~b}$ & $7,78 \mathrm{~b}$ & $1,51 \mathrm{~b}$ \\
9. & $\mathrm{j} 3 \mathrm{k} 3$ & $8,09 \mathrm{a}$ & $1,12 \mathrm{~d}$ & $77,65 \mathrm{a}$ & $2,73 \mathrm{~d}$ & $8,68 \mathrm{e}$ & $1,73 \mathrm{c}$ \\
\hline
\end{tabular}

Processed data, 2017

Description: number followed with the same letter showed no significant difference at $95 \%$ level of confidence $(P<0.05)$

On the other hand, rice analog with 90\% mocaf flour and 10\% mung bean has highest carbohydrate content compared to other formula, which has carbohydrate content around $77,65 \%-79,63 \%$. This might happen due to use of flour and starch that has high carbohydrate content. Carbohydrate has function as energy source, its fulfilled $60-70 \%$ human body energy needs and determined foods characteristics such as taste, colour and texture.

Fibers content in the rice analog made it more competitive compared to conventional rice. Fiber source come from mocaf flour, banana flour, corn flour and mung bean flour. The highest crude fiber content (table 5) were obtained by rice analog with composition of $80 \%$ banana flour and 20\% mung bean; and $70 \%$ corn flour and 30\% mung bean flour. Food fiber is part of carbohydrates that hard to digest, which has necessary characteristic and considered as important component in functional food formula (Jones, 2013; Kaczmarczyk et al, 2012; Noviasari et al, 2013).

Water content play important role in food deterioration process. Water content determined the foods freshness and endurance of foods. Low water content in rice intended to preserve the rice. Water content in agriculture products determine its resistance to microbial infection. This rice analog water content was lower than $12 \%$ therefore it is still unsuitable low for fungal growth. water content of rice analog was still under the required in Indonesia National Standard for rice which is $14 \%$ (BSN, 2015)

Decrease of water content in food material during drying process could cause an increase in carbohydrate content. 
Generally, carbohydrate content in dried foods higher than fresh foods. Drying process will reduce water content of foods, after the foods dried, the carbohydrates contents were higher than flour.

Protein, fat and carbohydrates is component to fulfil energy required by human. Due to that reason, rice consumption were higher compared to other protein sources (Agusman et al, 2014; Noviasari et al, 2013). Foods energy value can be calculated through composition of carbohydrates, fat and protein. Foods calorie equals to four times protein content plus 9 times fat content plus four times carbohydrates content with unit kkal/100 g.

Table 6. Energy content of rice analog

\begin{tabular}{cc}
\hline Formula & $\begin{array}{c}\text { Energy }(\mathrm{kkal}) / 100 \\
\text { gram }\end{array}$ \\
\hline $\mathrm{m} 1 \mathrm{k} 1$ & 363,19 \\
$\mathrm{~m} 2 \mathrm{k} 2$ & 351,41 \\
$\mathrm{~m} 3 \mathrm{k} 3$ & 358,78 \\
$\mathrm{p} 1 \mathrm{k} 1$ & 353,56 \\
$\mathrm{p} 2 \mathrm{k} 2$ & 355,18 \\
$\mathrm{p} 3 \mathrm{k} 3$ & 359,08 \\
$\mathrm{j} 1 \mathrm{k} 1$ & 359,83 \\
$\mathrm{j} 2 \mathrm{k} 2$ & 365,95 \\
$\mathrm{j} 3 \mathrm{k} 3$ & 353,04 \\
\hline
\end{tabular}

Rice analog from locally available foods source and mung bean flour contribute 351.41-365.95 kkal/100 gram. Its energy content equals to energy of conventional rice $360 \quad \mathrm{kkal} / 100$ gram (Departemen Kesehatan RI, 2005).

\section{Organoleptic characteristic of rice analog}

Panelists assessment results to sensory attribute of rice analog that showed panelist preference towards color, scent, taste and overall appearance were significantly difference at $95 \% \quad(\mathrm{P}<0.05)$ level of confidence. Rice analog that has high preference from panelist from color, scent and overall was rice analog made from mocaf flour and mung bean. From its texture, according to panelist opinion, it has no significant difference compared to other treatment. Table 7 showed that panelists hedonic score on rice analog color was 4,02-5,92 (neutral to preferable). Highest preference obtained by mocaf flour with 5,92 .

Table7. Preference test of rice analog

\begin{tabular}{lccccc}
\hline \multirow{2}{*}{ Main ingredients } & \multicolumn{5}{c}{ Test Parameter } \\
\cline { 2 - 5 } & Colour & Aroma & Texture & Flavour & Overall \\
\hline Mocaf flour & $5,92^{\mathrm{b}}$ & $5,57^{\mathrm{b}}$ & $5,23^{\mathrm{a}}$ & $5,82^{\mathrm{b}}$ & $5,883^{\mathrm{c}}$ \\
Banana Flour & $4,02^{\mathrm{a}}$ & $4,13^{\mathrm{a}}$ & $5,12^{\mathrm{a}}$ & $4,37^{\mathrm{a}}$ & $4,40^{\mathrm{a}}$ \\
Corn Flour & $4,43^{\mathrm{a}}$ & $4,08^{\mathrm{a}}$ & $5,13^{\mathrm{a}}$ & $4,30^{\mathrm{a}}$ & $5,27^{\mathrm{b}}$ \\
\hline
\end{tabular}

Processed data, 2017

Description: number followed with the same letter showed no significant difference at $95 \%$ level of confidence $(P<0.05)$

\section{CONCLUSION}

Utilization of cassava, kepok banana and corn to produce rice analog that has different color and texture. The best formula based on organoleptic test was formula with
$80 \%$ cassava flour and $20 \%$ mung bean. Proximate analysis showed rice analog has protein $8,24 \%$, fat $0,73 \%$, carbohydrates $77,97 \%$, fiber $1,87 \%$, water content $9,72 \%$, and ash content $1,47 \%$. 
Organoleptic analysis showed that the most rice analog made of mocaf flour was preferred from favorable rice analog made of banana flour and rice analog made from corn flour.

\section{REFERENCES}

Agusman, A., Kartika Apriani, S. N., \& Murdinah, M. 2014. Penggunaan Tepung Rumput Laut Eucheuma cottonii pada Pembuatan Beras Analog dari Tepung Modified Cassava Flour (MOCAF). Jurnal Pascapanen Dan Bioteknologi Kelautan Dan Perikanan, 9 (1): 1-10. https://doi.org/10.15578/jpbkp.v9i1.9 4

AOAC. 1996. Official method 968.08: Minerals in animal feed and pet foodAtomic absorption spectrophotometric method. , Pub. L. No. 968.08, 12.

Aini, N., Hariyadi, P., Muchtadi, T. R., \& Andarwulan, N. 2010. Hubungan antara Waktu Fermentasi Grits Jagung dengan Sifat Gelatinisasi Tepung Jagung Putih yang dipengaruhi Ukuran Partikel. Jurnal Teknologi Dan Industri Pangan, 21 (1): 18-24.

Amanu, F. N., \& Susanto, W. H. 2014. Pembuatan Tepung Mocaf di Madura (Kajian Varietas dan Lokasi Penanaman) Terhadap Mutu dan Rendemen. Jurnal Pangan Dan Agroindustri, 2 (3): 161-169. https://jpa.ub.ac.id/index.php/jpa/artic le/view/64

Bosawer, F. E. 2010. Komposisi Kimia danKarakteristik Fisik Pati Ubi Kayu (Manihotesculenta) Asal Distrik Masni Kabupaten Manokwari. Skripsi Universitas Negeri Papua.

BPS. 2017. Katalog Provinsi Bengkulu dalam Angka. Badan Pusat Statistik Provinsi Bengkulu. Bengkulu.
BSN. 2015. Beras. , Pub. L. No. 6128:2015, 17.

Budi, F. S., Hariyadi, P., Buijanto, S., \& Syah, D. 2013. Teknologi Proses Ekstrusi untuk Membuat Beras Analog. Pangan, 22(3): 263-274. https://doi.org/10.1021/cm050787y

Budijanto, S., \& Yuliyanti. 2012. Studi Persiapan Tepung Sorgum (Sorghum bicolor L. Moench) dan Aplikasinya pada Pembuatan Beras Analog Study. Jurnal Teknologi Pertanian, 13 (3): 177-186.

Departemen Kesehatan Republik Indonesia. 2005. Daftar Komposisi Bahan Makanan. Bhratara Karya Aksara. Jakarta.

Fairhurst, T. H., \& Dobermann, A. 2002. Rice in the Global Food Supply. In Better Crops International 16 (Special Supplement): 3-6.

FAO. 2016. Save and grow in practice: maize, rice and wheat. A guide to sustainable cereal production. FAO.Rome

Harefa, W., \& Pato, U. 2017. Evaluasi Tingkat Kematangan Buah terhadap Mutu Tepung Pisang Kepok yang Dihasilkan. JOM FAPERTA, 4(2): 112.

Jamal, K., Kamarulzaman, N. H., Abdullah, A. M., Ismail, M. M., \& Hashim, M. 2014. Adoption of Fragrant Rice Farming: The Case of Paddy Farmers in the East Coast Malaysia. UMK Procedia, 1, 8-17. International Agribusiness Marketing Conference 2013, IAMC 2013, 22-23 October 2013, Kuala Lumpur, Selangor, Malaysia. https://doi.org/10.1016/j.umkpro.2014 .07 .002 
Jones, J. M. 2013. Dietary fiber future directions: Integrating new definitions and findings to inform nutrition research and communication. Advances in Nutrition, 4 (1): 8-15. https://doi.org/10.3945/an.112.002907

Kaczmarczyk, M. M., Miller, M. J., \& Freund, G. G. 2012. The health benefits of dietary fiber: Beyond the usual suspects of type 2 diabetes mellitus, cardiovascular disease and colon cancer. Metabolism: Clinical and Experimental, 61 (8):. 10581066.https://doi.org/10.1016/j.metabol .2012.01.017

Mohanty, S., Wailes, E., \& Chavez, E. 2010. The global rice supply and demand outlook: the need for greater productivity growth to keep rice affordable. In Rice in the Global Economy: Strategic Research and Policy Issues for Food Security, 175188. IRRI. Manila.

Muthayya, S., Sugimoto, J. D., Montgomery, S., \& Maberly, G. F. 2014. An overview of global rice production, supply, trade, and consumption. Annals of the New York Academy of Sciences, 1324 (1): 7-14. https://doi.org/10.1111/nyas.12540
Noviasari, S., Kusnandar, F., \& Budijanto, S. 2013. Pengembangan Beras Analog dengan Memanfaatkan Jagung Putih. Jurnal Teknologi Dan Industri Pangan, 24 (2): 194-200. doi.org/10.6066/jtip.2013.24.2.194

Soekarto, S. T. 1985. Penelitian Organoleptik untuk Industri Pangan dan Hasil Pertanian. Bhratara Karya Aksara. Jakarta

USDA. 2014. Rice, White, Long-Grain, Parboiled, Unenriched, Cooked, Nutrients United States Departement of Agriculture. https://fdc.nal.usda. gov/fdc-app.html\#/food-details/16975 9/nutrients

Yuwono, S. S., \& Zulfiah, A. A. 2015. Formulasi Beras Analog Berbasis Tepung Mocaf dan Maizena dengan Penambahan CMC dan Tepung Ampas Tahu. Jurnal Pangan dan Agroindustri 3 (4): 1467-1472 https://jpa.ub.ac.id/index.php/jpa/artic le/view/270

Zeigler, R. S., \& Barclay, A. 2008. The Relevance of Rice. Rice. 1 (1): 3-10. https://doi.org/10.1007/s12284-0089001-z 